\title{
Quantitative Fluorescent Polymerase Chain Reaction for Prenatal Diagnosis and its application in Vietnam: A literature review
}

\author{
Thuan Phan ${ }^{1,2}$ \\ ${ }^{1}$ Department of Women's and Children's Health, University of Liverpool, UK \\ ${ }^{2}$ Department of Delivery, Tu Du Hospital, Ho Chi Minh City, Vietnam \\ Correspondence: p.thuan@liverpool.ac.uk or drthuanphan@hotmail.com
}

\begin{abstract}
Early identification of fetal abnormalities is a huge challenge for modern obstetrics. Quantitative fluorescent polymerase chain reaction (QF-PCR) has quickly become an effective means of chromosome anomaly detection due to its advantages in terms of timing, manpower and accuracy. The QF-PCR results also make a significant change in clinicians' attitude to some extent, assisting them providing parents with professional and valuable advice on pregnancy management. In this review, the advantages and drawbacks of QF-PCR will be explored. By reviewing studies published in Vietnamese Medical Journals, we conclude QF-PCR can become a potential screening test in the field of prenatal diagnosis.
\end{abstract}

Keywords: QF-PCR, cytogenetics, prenatal diagnosis, aneuploidy, chromosome abnormalities, screening test. 


\section{Introduction}

Chromosome abnormalities are considered one of the causes of birth defects, mental and physical retardation, disorders of the sex chromosomes, and miscarriage. They are described as either a morphological abnormality or a numerical transformation of chromosomes which can be autosomes, gender chromosomes or both. Numerical alterations are significantly more usual than morphological abnormalities; they include all anomalies in the normal diploid number for human beings. On the contrary, structural abnormalities consist of fundamental alterations related to genomic arrangements of the chromosomes [1]. Additionally, chromosome abnormalities are also classified as constitutional or acquired anomalies. Constitutional chromosome abnormalities have marked effect on all or a vast majority of cells in the whole body, whilst acquired anomalies only affect one clone of cells and are distributed in a determined organ of the body [2].

Prenatal diagnosis has contributed to early identification of innate abnormalities or genetic disorders through initial screening for birth defects in the first months of pregnancy. Ultrasound, considered one of the initial screening methods by evaluating malformations of foetus, was applied from the 1950s of the last century and has become an outstanding and frequently used tool in daily obstetric care [3]. At that time, amniocentesis was also first described as a chromosomal diagnostic test and is recently utilised for infectious assessment and genetic screening. Non-invasive tests for prenatal diagnosis, such as maternal serum and cell-free Deoxyribonucleic Acid (DNA) screening, were then developed to early screen for genetic anomalies. Early diagnosis of genetic disorders in utero emphasises the vital necessity of pregnancy management, particularly prenatal period $[4,5]$. Under the rapid development of science and technology in the field of cytogenetics, there have been various techniques 
developed and applied effectively for chromosome analysis in the area of prenatal diagnosis. The three main techniques utilised for the identification of chromosome anomalies are karyotyping, fluorescent in-situ hybridisation (FISH) and QF-PCR.

Vietnam located in Southeast Asia is considered one of lower middle-income countries. Despite a late commence, prenatal diagnosis services in Vietnam have developed speedily under the support of the government. In 2007, to develop and widely disseminate prenatal screening practices, a national project was launched; shortly thereafter, several prenatal diagnosis centres were established across the country [6]. However, statistics related to chromosome anomaly detection as well as results of the application of cytogenetic analysis techniques have not been reported adequately due to the lack of scientific research.

The purpose of this review is to gain the basic understanding of advantages and drawbacks of QF-PCR in the field of prenatal diagnosis and to preliminarily examine its application in Vietnam through reviewing several existing studies.

\section{QF-PCR for prenatal diagnosis}

From the middle of 1950s, the determination of Down syndrome aetiology would call for action from scientists in the area of correct human chromosome assessment. Pregnant women at high risk of trisomy 21 identified by maternal age and ultrasound marker approaches were then provided a diagnostic test as a screening test for Down syndrome [7]. At the end of 1960s, karyotype analysis of cultured cell samples collated from amniotic fluid and then from chorionic villus were also applied to detect not only trisomy 21 but also other chromosome abnormalities. However, this process normally takes approximately 14 days to produce a result, whilst pregnant women at increased risk truly need a rapid confirmation to 
have plans for their pregnancy management. Until the middle of 1990s, the application of FISH technique was introduced as a quicker test from uncultured cell samples to identify trisomy 21; this method only takes around $24-48$ hours. Additionally, by utilising probes specific to chromosome 13, 18 and sex chromosome, FISH technique allows to detect other chromosome anomalies such as Patau syndrome, Edwards syndrome, and sex chromosome aneuploidies [8]. Nevertheless, because FISH requires hard manual labour and fluorescent probes used in this method are costly, it cannot afford high-risk women an opportunity for early chromosome abnormality detection due to a significantly burgeoning demand from patients and even from obstetricians.

The introduction of QF-PCR has solved the problems faced by previous techniques, particularly the problem of timing. QF-PCR has been developed for rapid diagnosis of chromosome anomalies by examining and quantifying chromosome-specific DNA sequences (short tandem repeats - STR). The amplification of these repeat sequences is carried out by Polymerase Chain Reaction (PCR) and visualised by applying fluorescent primers. Two equal peaks within the same region of chromosome illustrated by an automated DNA scanner show a normal heterozygous case, whereas three peaks or two peaks with the ratio of 2:1 are diagnostic of trisomy [9].

Compared to FISH technique, several studies indicated that QF-PCR has enormous and definite advantages. Due to being operated by automated systems, QF-PCR is considered being more robust and less laborious, and a great number of specimens are processed simultaneously. Furthermore, when samples are collated with fewer cells, QF-PCR is also viable. In case of female foetuses, FISH cannot detect a contamination with maternal cells, but QF-PCR can [10-12]. Hence, QF-PCR swiftly entered the area of prenatal diagnosis as an 
effective, potential, and sophisticated technique. However, QF-PCR has also faced several obstacles. Although this technique is widely considered an affordable method for prenatal screening, the cost-effectiveness of QF-PCR completely depends on a throughput of specimens. In other words, the more samples laboratory has, the more financial benefit it receives. Moreover, all DNA analysis centres need the necessary equipment and prioritise prenatal diagnosis; it seems particularly difficult for small laboratories to maintain activities of DNA analysers which must be always available [13].

According to several authors, QF-PCR should be considered as a stand-alone screening test in a huge number of prenatal samples $[14,15]$. Of the applied cytogenetic techniques, QF-PCR with its specific characteristics appears to be the only method which can be conducted in the huge mass of samples. This is an enormous benefit since QF-PCR assists obstetricians in screening a great number of patients with low-risk results of biochemical tests but abnormal ultrasound findings. However, all information related to risks of fetal anomalies should be provided appropriately for parents; this allows them to select screening test so that they can afford it and feel comfortable when waiting for a confirmed result.

QF-PCR actually plays a vital role in prenatal diagnosis with the sensitivity up to $99.99 \%$ [15]. This sophisticated technique not only assists parents in avoiding increasing nervousness inextricably linked to vague results of prenatal diagnostic tests, but also prevents strictly unnecessary termination of pregnancy.

\section{Application of QF-PCR for prenatal diagnosis in Vietnam}

The application of QF-PCR in prenatal prognosis has been increasingly common in the Western countries since the mid-1990s, yet this method was adopted in Vietnam from 2010 
under the official and technical support of the government [6]. There were three prenatal diagnosis centres established and operated by governmental female hospitals across the country at that time. Depending on the equipment of each centre, three techniques including karyotype, FISH and QF-PCR would be considered for the application in prenatal diagnosis. With the participation of the private medical activities in this field, the provision of antenatal services has been becoming increasingly popular and affordable. Although there has been no specific statistics, until 2015 it was estimated that approximately $40 \%$ of pregnant women could access prenatal diagnosis services $[6,16]$.

More recently, QF-PCR has been applied widely in most prenatal diagnosis centres across the country as a stand-alone screening test. However, there has been a lack of convincing and concrete evidence to prove the effectiveness of the QF-PCR application in prenatal diagnosis in Vietnam, as well as a systematically comprehensive assessment of advantages and drawbacks when utilising this technique. We explored three largest national databases managed by three Vietnamese universities of medicine such as Hanoi Medical University, University of Medicine and Pharmacy at Ho Chi Minh City and Vietnam Military Medical University and found seven articles related to the application of QF-PCR. The characteristics of these studies are summarised in Table 1.

In six of seven studies, the authors utilised QF-PCR to detect numerical chromosome abnormalities. After comparing with results from other techniques such as karyotype, FISH or multiplex ligation-dependent probe amplification (MLPA), the sensitivity of QF-PCR was determined to be $100 \%$ [17-22]. Oanh Quach et al. (2015) also applied this technique to more than 5,000 samples and compared these QF-PCR results with results collated from noninvasive screening tests including biochemical tests and ultrasound scan. The authors have 
also recognised and emphasised the importance of QF-PCR in prenatal screening and diagnosis to detect aneuploidies [16]. Furthermore, all authors of these papers also suggested that QF-PCR could completely become a potentially stand-alone screening test for early diagnosis of numerical chromosome anomalies. Simultaneously, it has been considered an effective tool for in-depth studies in the area of prenatal diagnosis.

Table 1: Characteristic of studies on the application of QF-PCR in prenatal diagnosis in Vietnam

\begin{tabular}{|c|c|c|c|c|c|}
\hline Studies & Objectives & $\begin{array}{l}\text { Sample } \\
\text { size }\end{array}$ & $\begin{array}{l}\text { Prenatal } \\
\text { diagnostic } \\
\text { tests }\end{array}$ & Results & $\begin{array}{l}\text { Sensitivity } \\
\text { of QF-PCR }\end{array}$ \\
\hline $\begin{array}{l}\text { Sang TT } \\
(2010) \\
{[17]}\end{array}$ & $\begin{array}{l}\text { To apply and adjust QF-PCR technique } \\
\text { in prenatal diagnosing chromosome } \\
\text { numerical disorders and to evaluate } \\
\text { the detection power and accuracy of } \\
\text { QF-PCR approach. }\end{array}$ & 42 & $\begin{array}{l}\text { - FISH } \\
\text { - QF-PCR }\end{array}$ & $\begin{array}{l}\text { Trisomy 13: } 1 \\
\text { Trisomy 18: } 2 \\
\text { Trisomy 21: } 28 \\
\text { Klinefelter Syndrome: } 1 \\
\text { Turner Syndrome: } 2 \\
\end{array}$ & $100 \%$ \\
\hline $\begin{array}{l}\text { Huyen NT } \\
\text { (2011) } \\
{[18]}\end{array}$ & $\begin{array}{l}\text { To assess the accuracy of QF-PCR using } \\
\text { Aneufast kit in prenatal diagnosing } \\
\text { some major numerical chromosome } \\
\text { disorders. }\end{array}$ & 60 & $\begin{array}{l}\text { - Karyotype } \\
\text { - QF-PCR }\end{array}$ & $\begin{array}{l}\text { Trisomy 13: } 5 \\
\text { Trisomy 18: } 15 \\
\text { Trisomy 21: } 25 \\
\text { Klinefelter Syndrome: } 1 \\
\text { Turner Syndrome: } 3 \\
\end{array}$ & $100 \%$ \\
\hline $\begin{array}{l}\text { Thong NV } \\
\text { (2011) } \\
{[19]}\end{array}$ & $\begin{array}{l}\text { To test and compare whether FISH, QF- } \\
\text { PCR, and MLPA can be used for the } \\
\text { detection of common aneuploidy of } \\
\text { chromosomes } 13,18 \text {, and } 21, X \text {, and Y } \\
\text { in uncultured amniocytes. }\end{array}$ & 65 & $\begin{array}{l}\text { - FISH } \\
\text { - MLPA } \\
\text { - QF-PCR }\end{array}$ & $\begin{array}{l}\text { Trisomy 18: } 2 \\
\text { Trisomy 21: } 3 \\
\text { Klinefelter Syndrome: } 3 \\
\text { Turner Syndrome: } 1 \\
\text { Female triploidy: } 1 \\
\end{array}$ & $100 \%$ \\
\hline $\begin{array}{c}\text { Lan H } \\
(2012) \\
{[20]}\end{array}$ & $\begin{array}{l}\text { To assess the value of QF-PCR in } \\
\text { prenatal diagnosis for fetal } \\
\text { aneuploidies. }\end{array}$ & 31 & $\begin{array}{l}\text { - Karyotype } \\
\text { - QF-PCR }\end{array}$ & $\begin{array}{l}\text { Trisomy 13: } 2 \\
\text { Trisomy 18: } 8 \\
\text { Trisomy 21: } 16 \\
\text { Turner Syndrome: } 1 \\
\end{array}$ & $100 \%$ \\
\hline $\begin{array}{l}\text { Hoan NKH } \\
(2013) \\
{[21]}\end{array}$ & $\begin{array}{l}\text { To evaluate the values of QF-PCR in } \\
\text { fast prenatal diagnosis of chromosome } \\
\text { disorders. }\end{array}$ & 400 & $\begin{array}{l}\text { - Karyotype } \\
\text { - QF-PCR }\end{array}$ & $\begin{array}{l}\text { Trisomy 13: } 6 \\
\text { Trisomy 18: } 10 \\
\text { Trisomy 21: } 11 \\
\text { Klinefelter Syndrome: } 1 \\
\text { Turner Syndrome: } 2 \\
\text { Trisomy X: } 1 \\
\text { Triploidy: } 2\end{array}$ & $100 \%$ \\
\hline $\begin{array}{l}\text { Ngoc HH } \\
(2014) \\
{[22]}\end{array}$ & $\begin{array}{l}\text { To detect aneuploidies in amniotic } \\
\text { fluids from high-risk pregnancies. }\end{array}$ & 64 & $\begin{array}{l}\text { - Karyotype } \\
\text { - QF-PCR }\end{array}$ & $\begin{array}{l}\text { Trisomy 18: } 3 \\
\text { Trisomy 21: } 3 \\
\text { Klinefelter Syndrome: } 3 \\
\text { Turner Syndrome: } 1\end{array}$ & $100 \%$ \\
\hline $\begin{array}{l}\text { Oanh Quach } \\
\text { (2015) } \\
{[16]}\end{array}$ & $\begin{array}{l}\text { To evaluate the correlations between } \\
\text { the screening test, ultrasonography } \\
\text { results and results of chromosomal } \\
\text { analysis on fetal cells. }\end{array}$ & 5557 & - QF-PCR & $\begin{array}{l}\text { Trisomy 13: } 11 \\
\text { Trisomy 18: } 78 \\
\text { Trisomy 21: } 132 \\
\text { Other abnormalities: } 21\end{array}$ & $\begin{array}{l}\text { Not } \\
\text { reported }\end{array}$ \\
\hline
\end{tabular}

Due to differences in the management and operation of health systems between countries,

the assessment of advantages as well as disadvantages should be based on the actual conditions of each nation. Similar to opinions of international experts, Vietnamese specialists 
through their studies also state that QF-PCR is judged an exceptionally rapid screening test with high accuracy and can be applied on a massive scale with an enormous number of samples. However, there are still differences in the perception of the concept "costeffectiveness". In the developed countries, typically the UK, medical expenses of patients are covered by a government-managed social welfare system, so it is important to understand this cost-effectiveness is related to economic success of government investment in health area. On the other hand, in low-income countries such as Vietnam, patients have to pay the medical expenses in full or in part, therefore cost-effectiveness should be comprehended that they can afford this prenatal service to obtain an accurate screening result in a short period of time. All these seven studies stated that regarding medical cost, QF-PCR is in fact an affordable approach to prenatal diagnosis.

With regard to drawbacks of QF-PCR, several chromosome anomalies such as structural disorders and mosaic cannot be detected by this method [20, 21]. Additionally, QF-PCR technique only allows to determine abnormalities in chromosome $13,18,21, X$ and $Y[20,22]$, and its results can be affected if the amniotic fluid or chorionic villus sample contains mother blood cells [20]. Moreover, the most obvious disadvantages of QF-PCR application are to equip laboratory with PCR machines as well as maintain the operation of small diagnosis centres where few samples are collated.

The application of QF-PCR in Vietnam has contributed to the change of obstetricians' attitude to prenatal diagnosis $[21,22]$. The result of QF-PCR screening test brings clinicians more precisely additional information, providing decisive evidence to assist them offering high-risk women counselling for their pregnancies. Furthermore, the QF-PCR result also plays a vital role in putting a stop to lingering fear and anxiety of parents, helping them reaching a tough 
decision on their pregnancies. In addition, QF-PCR to some extent contributes to significantly reduce the rate of unnecessary termination.

\section{The future of QF-PCR}

QF-PCR will perform a leading role in prenatal diagnosis in the future. With outstanding features, QF-PCR will continue to be an effective means of chromosome abnormality detection due to its benefits in terms of timing, manpower and accuracy. Although the introduction of non-invasive screening tests for detecting chromosome abnormalities will be made with the great sensitivity and specificity, leading lower demand for invasive techniques, QF-PCR should be chosen for those at a high risk of Down syndrome or other aneuploidies to rapidly validate the screening result prior to termination of pregnancy. Additionally, when detecting fetal abnormalities by ultrasound scanning at women with low-risk result of noninvasive screening tests, QF-PCR should be indicated in these situations to deny the existence of trisomy instead of costlier tests for the whole genome.

\section{Conclusion}

QF-PCR is applied in prenatal diagnosis as an accurate, less labour-intensive, less timeconsuming method. It assists to detect numerical chromosome abnormalities rapidly but has limitations of structural chromosome anomalies and mosaic identification. The application of this technique in low- and middle-income countries, typically as Vietnam, has initially brought remarkable success and promisingly contributes to an unexpected development of prenatal diagnosis. 


\section{Funding}

This review received no external funding.

\section{Acknowledgements}

I would like to express my deepest appreciation to Professor Dharani K Hapangama (University of Liverpool), who provided me the possibility to complete this report and helped me to coordinate my report, especially in writing.

\section{Disclosure of interests}

The author declares no competing interests.

\section{Contribution to Authorship}

Not applicable

\section{Details of Ethics Approval}

Not applicable

\section{Authors' contributions}

Not applicable 


\section{References}

1. McFeely, R. A., Chromosome abnormalities. Vet Clin North Am Food Anim Pract 1993, $9(1), 11-22$.

2. McFadden, D. E.; Friedman, J. M., Chromosome abnormalities in human beings. Mutat Res 1997, 396 (1-2), 129-40.

3. Bianci, D.; Crombleholme, T.; D'Alton, M.; Malone, F. In Fetology: diagnosis and management of the fetal patient 2nd edition, 2010.

4. Vora, N. L.; O'Brien, B. M., 2 - Prenatal Diagnosis. In Fetal and Neonatal Physiology (Fifth Edition), Polin, R. A.; Abman, S. H.; Rowitch, D. H.; Benitz, W. E.; Fox, W. W., Eds. Elsevier: 2017; pp 14-23.e1.

5. Stembalska, A.; Slezak, R.; Pesz, K.; Gil, J.; Sasiadek, M., Prenatal diagnosis--principles of diagnostic procedures and genetic counseling. Folia Histochem Cytobiol 2007, 45 Suppl 1, S11-6.

6. Ha, B. T. T.; Huong, N. T. T.; Duong, D. T. T., Prenatal diagnostic services in three regional centers in Vietnam. International journal of public health 2017, 62 (1), 27-33.

7. Norton, M. E., Biochemical and ultrasound screening for chromosomal abnormalities. Semin Perinatol 1994, 18 (4), 256-65.

8. Klinger, K.; Landes, G.; Shook, D.; Harvey, R.; Lopez, L.; Locke, P.; Lerner, T.; Osathanondh, R.; Leverone, B.; Houseal, T.; et al., Rapid detection of chromosome aneuploidies in uncultured amniocytes by using fluorescence in situ hybridization (FISH). Am J Hum Genet 1992, 51 (1), 55-65. 
9. Mansfield, E. S., Diagnosis of Down syndrome and other aneuploidies using quantitative polymerase chain reaction and small tandem repeat polymorphisms. Hum Mol Genet 1993, 2 (1), 43-50.

10. Ogilvie, C. M., Prenatal diagnosis for chromosome abnormalities: past, present and future. Pathologie Biologie 2003, 51 (3), 156-160.

11. Leung, W. C.; Lau, E. T.; Lao, T. T.; Tang, M. H., Rapid aneuploidy screening (FISH or QF-PCR): the changing scene in prenatal diagnosis? Expert Rev Mol Diagn 2004, 4 (3), 333-7. 12. Nicolini, U.; Lalatta, F.; Natacci, F.; Curcio, C.; Bui, T. H., The introduction of QF-PCR in prenatal diagnosis of fetal aneuploidies: time for reconsideration. Hum Reprod Update 2004, $10(6), 541-8$.

13. Mann, K.; Ogilvie, C. M., QF-PCR: application, overview and review of the literature. Prenatal Diagnosis 2012, 32 (4), 309-314.

14. Badenas, C.; Rodríguez-Revenga, L.; Morales, C.; Mediano, C.; Plaja, A.; PérezIribarne, M. M.; Soler, A.; Clusellas, N.; Borrell, A.; Sánchez, M. Á.; Miró, E.; Sánchez, A.; Milà, M.; Jiménez, W., Assessment of QF-PCR as the First Approach in Prenatal Diagnosis. The Journal of Molecular Diagnostics 2010, 12 (6), 828-834.

15. Hills, A.; Donaghue, C.; Waters, J.; Waters, K.; Sullivan, C.; Kulkarni, A.; Docherty, Z.; Mann, K.; Ogilvie, C. M., QF-PCR as a stand-alone test for prenatal samples: the first 2 years' experience in the London region. Prenat Diagn 2010, 30 (6), 509-17.

16. Oanh Quach, T. H.; Trang Bui, K. Y.; Hoang Nguyen, T. N.; Phu Tran, N. A.; Anh Nguyen, T. L., AB135. The numerical chromosomal abnormalities in prenatal screening and diagnosis by QF-PCR. Ann Transl Med 2015, 3 (Suppl 2), AB135. 
17. Sang, T. T.; Bac, N. D.; Khoa, T. V., Study of applying QF-PCR assay for detection of major chromosome numerical disorders. Journal of Military Pharmacy and Medicine 2010, 7, 41-44.

18. Huyen, N. T.; Sang, T. T.; Bac, N. D., Applying QF-PCR assay in prenatal diagnosing some major numerical disorders. Journal of Military Pharmacy and Medicine 2011, 8, 26-32. 19. Thong, N. V.; Hiep, K.; Ngoc, H. H.; Van, P. H., Application and experience in the use of rapid tests (FISH, MLPA and QF-PCR) to detect common chromosome abnormalities in prenatal diagnosis. Medical Journal of Ho Chi Minh City 2011, 15.

20. Lan, H.; Nam, N. H.; Khanh, T. V., Application of QF-PCR in prenatal diagnosis for fetal aneuploidies. Journal of Medical Research 2012, 80 (3D), 1-6.

21. Hoan, N. K. H.; Toan, P. N.; Oanh, Q. T. H.; Phu, T. N. A.; Hoang, N. T. N., Values of QF-PCR in fast prenatal diagnosis of chromosome disorders. Medical Journal of Ho Chi Minh City 2013, 17, 149-156.

22. Ngoc, H. H.; Trang, P. T. H.; Van, P. H.; Thong, N. V.; Hiep, K., Rapid prenal diagnosis by quantitative fluorescent polymerasechain reaction to detect human aneuploidies in amniotic fluids. Medical Journal of Ho Chi Minh City 2014, 18, 144-149. 